\title{
Lip twitch restraint on rebound tonometry in horses
}

\author{
Contenção com cachimbo na tonometria de rebote em cavalos
}

\begin{abstract}
Maria Cristina Caldart de Andrade ${ }^{I}$ Paula Stieven Hünning ${ }^{\mathrm{I}}$ Fabiana Quartiero Pereira ${ }^{\mathrm{I}}$ Kadigia Pitol Dutra ${ }^{I}$ João Antonio Tadeu Pigatto ${ }^{I^{*}}$
\end{abstract}

\section{ABSTRACT}

The purpose of this study was to verify the effect of the upper lip twitch restraint on intraocular pressure (IOP) of healthy horses. In this study, forty five Criollo horses, aged between two to 20 years (male or female) were evaluated with rebound tonometer, with and without upper lip twitch restraint. A previous ophthalmic examination was performed with Schirmer tear test, fluorescein test, slit lamp biomicroscopy and direct ophthalmoscopy in all horses. Only healthy animals with no ocular findings were used. The order of the IOP measurements (with or without twitch) and order of the eye (right or left) were randomized. Three measurements of each eye were made and the mean was calculated. Head position was kept above the heart level and no pressure was made over eyelids. At least 10 minutes passed between the evaluations of the same horse. Measurements were made between 3:30 and 5:30pm to avoid circadian fluctuation of intraocular pressure. Statistical analysis was performed with SAS 9.2 software. A Split plot factorial design was used where horses were considered blocks. The mean intraocular pressure values obtained with lip twitch restraint $(34.68 \pm 6.47 \mathrm{mmHg})$ were significantly higher $(P<0.05)$ than those obtained without $(29.35 \pm 4.08 \mathrm{mmHg})$. There was no relevant statistical difference between right and left eyes. The restraint of horses with upper lip twitch increased equine intraocular pressure measured with the rebound tonometry.

Key words: equine, intraocular pressure, restraint, Tonovet.

RESUMO

O objetivo deste estudo foi avaliar o efeito da contenção pelo cachimbo na aferição da pressão intraocular em equinos hígidos. Neste trabalho, 45 cavalos Crioulos, com idade entre dois e 20 anos, machos ou fêmeas, foram avaliados utilizando tonometria de rebote, com e sem contenção, com cachimbo no lábio superior. Exame oftálmico prévio foi realizado, incluindo Teste Lacrimal de Schirmer, prova da fluoresceina, biomicroscopia com lâmpada de fenda e oftalmoscopia direta em todos os cavalos. Somente animais sadios com olhos hígidos foram utilizados. A ordem das tonometrias (com ou sem cachimbo) e a ordem dos olhos (direito e esquerdo) foram randomizadas. Três aferições de cada olho foram realizadas e a média calculada. A posição da cabeça dos cavalos foi mantida acima do nivel do coração e nenhuma pressão foi feita sobre as pálpebras. Ao menos 10 minutos se passaram entre as aferições do mesmo cavalo. As medidas foram realizadas entre as 15 h30min e 17h30min do mesmo dia, para evitar flutuações relacionadas ao ritmo circadiano da pressão intraocular. A análise estatística foi realizada com o programa SAS 9.2. Foi realizada análise de variância de parcela subdividida, onde o cavalo foi considerado bloco. A pressão intraocular média obtida com cachimbo $(34,68 \pm 6,47 \mathrm{mmHg})$ foi significativamente maior $(P<0,05)$ que a obtida sem $(29,35 \pm 4,08 \mathrm{mmHg})$. Não foi encontrada diferença significativa entre olhos direito e esquerdo. A contenção de equinos com o cachimbo aumentou significativamente a pressão intraocular aferida com tonômetro de rebote.

Palavras-chave: contenção, equino, pressão intraocular, Tonovet.

\section{INTRODUCTION}

The intraocular pressure (IOP) evaluation has been studied in humans and in various other animal species, both domesticated and wild. Assessment intraocular pressure is crucial parameter for a complete ophthalmic exam as it contributes to the diagnosis of ocular diseases. Several methods have been described for measuring IOP in animals, including applanation, indentation, and rebound tonometry (GUM et al., 1998; KNOLLINGER et al., 2005; WANG et al., 2005; BROADWATER

\footnotetext{
'Departamento de Medicina Animal, Faculdade de Veterinária, Universidade Federal do Rio Grande do Sul (UFRGS), Av. Bento Gonçalves, 9090, 91540-000, Porto Alegre, RS, Brasil. E-mail: pigatto@ufrgs.br. "Corresponding author.
} 
et al., 2007; RUSANEM et al., 2010; PEREIRA et al., 2011; PIGATTO et al., 2011). In animals, both applanation and rebound tonometry are used, and correlation has been revealed between these methods (KNOLLINGER et al., 2005). In horses, rebound tonometry has been used and intraocular pressure values of healthy horses ranged between 10 and $34 \mathrm{mmHg}$, with a mean value of $22.1 \pm 5.9 \mathrm{mmHg}$ (KNOLLINGER et al., 2005). Many authors have suggested tranquilization, auriculopalpebral nerve block and anesthetic eye drops to perform tonometry in horses (CARASTRO, 2004; WILKIE \& GILGER, 2004). However, use of these medications might underestimate IOP (TRIM et al., 1985; VAN DER WOERDT et al., 1995). The rebound tonometer does not require the use of topical anesthesia and has been tested in horses without tranquilization or restraint (KNOLLINGER et al., 2005). Nevertheless, in some cases to allow the realization of ophthalmic examination it will be necessary some form of containment. A method of restraint frequently used in horses is the lip twitch; however, it causes a rapid increase in concentrations of cortisol that could affect the aqueous humor balance (COLBORN et al., 1991). To the author's knowledge the effect of twitch on intraocular pressure has never been studied in horses. The objective of this study was to verify the effect of the upper lip twitch restraint on intraocular pressure of healthy horses.

\section{MATERIALS AND METHODS}

Animals

Forty five Criollo horses, aged between two to 20 years, (male or female) were used in this study. The horses were used for ridding, were housed in stables and were feed with commercial ration, hay and water ad libitum. All horses were considered healthy at the time of examination. The horses were periodically examined and were used to the ophthalmic exam, including tonometry, and used to the restraint method. The study was performed as part of the routine ophthalmic examination and conducted according to the Association for Research in Vision and Ophthalmology (ARVO) statement for the use of animals in ophthalmic and visual research. A previous ophthalmic examination was performed with Schirmer tear test (Teste Lacrimal de Schirmer, Ophthalmos, SP, Brazil), slit lamp biomicroscopy (Portable Slit Lamp SL 15, Kowa, Japan), direct ophthalmoscopy (Direct ophthalmoscope, WA 11720 , Welch Allyn, USA) and fluorescein test (Fluorescein strips, Ophthalmos, SP, Brazil). Only animals with no ocular findings were used. After the experiment, horses were examined for ocular disease weekly during a month and remained healthy.

Tonometry

All horses were submitted to the rebound tonometry (Tonovet, Thiols, Finland) with and without upper lip twitch restraint. Tonovet ${ }^{\circledR}$ was calibrated at mode "h" (horse) and result was checked at the LCD screen. The device software is able to detect erroneous measurements, in which case it shows an error message and does not accept the measurement. Measurements with any error signal were discarded in the current study. Horses were kept in their stables with a halter while the measurements were made. An experienced assistant placed the twitch in the upper lip of horses or hold the halter and the examiner started the tonometry. Rebound tonometry was performed three times consecutively, in both eyes, at vertical position. At least 10 minutes passed between the evaluations (with or without restraint) of the same horse. The order of the IOP measurements (with or without twitch) and order of the eye (right or left) were randomized at the time of measurements with a coin. No tranquilizers or regional nerve blocks were used at any stage of the study. Restraint was made by the same assistant and measurements were performed by the same examiner, experienced with the device use. Head position was kept above the heart level and any pressure was made over eyelids. Measurements were made between $3: 30$ and $5: 30 \mathrm{pm}$ to avoid circadian fluctuation of intraocular pressure. A mean IOP of the three measurements was calculated for statistical analysis.

\section{Statistical analysis}

Statistical analysis was performed with SAS 9.2 software $\left(\mathrm{SAS}^{\circledR}\right.$ Enterprise Guide $4.3^{\circledR}$, Cary, NC, USA). Statistical model was selected based on factors considered important when the data were analyzed. A difference between right and left eyes greater than $5 \mathrm{mmHg}$ is suggestive of uveitis (WADA, 2006). To ensure that horses were healthy and to compare right and left eyes of each horse and not the mean values, horses were assumed as blocks. ANOVA in a split plot factorial design was performed where the main factor is the twitch (with or without), the subplot factor is the eye (R e L), and "horses" and gender were considered blocks. Age was included in this model as a covariance, since it was significant $(\mathrm{P}<0.05)$. The "IOP" is the variable response. A $\mathrm{P}$ value $<0.05$ was considered significant. 


\section{RESULTS}

No ocular diseases were observed in these horses since data collection. Horses tolerated measurements with or without twitch restraint. IOP mean values without twitch restraint were $29.35 \pm 4.08 \mathrm{mmHg}$ and with the twitch were $34.68 \pm 6.47 \mathrm{mmHg}$ (Table 1). These values were statistically different $(\mathrm{P}<0.05)$. No significant differences were seen between the mean IOP values of the left eye compared to the right eye.

\section{DISCUSSION}

Nowadays, applanation and rebound tonometry have been used most frequently. In this study, rebound tonometer was used because it is portable, has a lower platinum, and its impact on the eye is fast and minimal. In addition, previous studies reported that measurement of IOP with this instrument was well tolerated in other species, being quick and inducing minimal stress (WANG et al., 2005). The choice of handheld tonometer used in this study was because it was available in the routine of study group, it has already been validated for horses and it does not require anesthetic drops or constant calibration. It can be used for IOP evaluation in awaked horses with no tranquilization or regional nerve block (KNOLLINGER et al., 2005). In the present study, the tonometer was easy to use and well tolerated by all horses. Moreover, two consecutive readings did not cause any ocular abnormalities, since horses were checked for ocular alterations for 30 days after experiment.

Our results showed that significant differences in IOP were not reported between the right and the left eyes, in accordance with previous results, which indicated that the IOPs are relatively constant in both healthy eyes from the same animal (KNOLLINGER et al., 2005; GERMANN et al., 2008).

There are many factors that can affect IOP, including species, age, gender, diurnal fluctuation, and stress. In addition, tonometry measurements vary according to the tonometer used and the examiner conducting the restraint (WHITACRE \& STEIN, 1993). Intraocular pressure mean values of this study are in accordance with previous findings in horses and fall within the reference values of intraocular pressure, (KNOLLINGER et al., 2005; GERMANN et al., 2008). Besides this fact, when intraocular pressures mean values with and without twitch restraint are compared, our data demonstrated increased intraocular pressure values with twitch. This effect on IOP had never been demonstrated, as far as the authors know. Stress response to twitch restraint has been studied in horses, revealing a strong hormone release from sympathetic nervous system activation (COLBORN et al., 1991). Furthermore, the role of sympathetic stimulation on aqueous humor production and intraocular pressure regulation has been studied. Large adrenergic innervations of the ciliary epithelium extending to ciliary body and the drainage system suggested that autonomic nervous system has a main role on intraocular pressure regulation (GWIN et al., 1979; TO et al., 2002). More research is required in horses to evaluate the effect of periocular muscles contraction on IOP, but horse's strong eyelid musculature leads us to believe that this effect is important for this measurements.

The ideal interval required between evaluations was not determined. Previous studies reported intervals of 1,2 , and 10 minutes (LEIVA et al., 2006; JEONG et al., 2007; LÓPEZ-CABALLERO et al., 2007; PEREIRA et al., 2011). Although these experiments were not using a "stress model", simply

Table 1 - Values of mean intraocular pressure (IOP) in mmHg of horses of different ages, measured with the rebound tonometer with and without twitch.

\begin{tabular}{|c|c|c|c|c|}
\hline \multirow{2}{*}{ Age (years) } & \multirow{2}{*}{ Horses (n) } & & 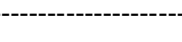 & \multirow{2}{*}{ Mean IOP } \\
\hline & & With twitch & Without twitch & \\
\hline $0-5$ & 12 & 28.91 & 25.58 & $27.27 \mathrm{~B}$ \\
\hline 06 a 10 & 16 & 36.65 & 29.56 & $33.12 \mathrm{~A}$ \\
\hline 11 a 15 & 10 & 37.81 & 30.95 & $34.38 \mathrm{~A}$ \\
\hline 16 a 20 & 6 & 35.33 & 31.25 & $33.29 \mathrm{~A}$ \\
\hline \multicolumn{2}{|c|}{----------------------Mean------------------ } & $34.68 \mathrm{a}$ & $29.35 b$ & \\
\hline
\end{tabular}

Means followed by different lowercase letters in each row and uppercase letters in each column differ significantly at $\mathrm{P}<0.05$ according to the Tukey's test.

Ciência Rural, v.46, n.8, ago, 2016. 
placing the tonometer in front of the eye or even the use of a contention method of rabbits or owls could lead to a stress hormone release. This study used an interval of 10 minutes between tonometries. In previous experiments of this study group (not published) intervals of 10 minutes, 30 minutes and 1 hour between tonometries with and without twitch were tested, but clinically these intervals were not different. Regardless of the order of measurements or interval time (10min, 30min and 1 hour), placing the twitch always overestimated IOP.

In the present study, younger horses had lower intraocular pressure values than older. A positive relation between corneal thickness and age was reported in Rocky Mountain Horses (RAMSEY et al., 1999) and several studies have noted a relationship between corneal thickness and IOP in humans (WHITACRE \& STEIN, 1993). In horses, corneal thickness has been studied in several breeds, but its relation with IOP was not established. Although corneal thickness was not measured, it could be assumed that young horses with thinner corneas could have lower IOP.

The study was performed between 3:30 and 5:30 pm of the same day. Horses are considered a diurnal specie with the acrophase (peak time) concentrated during the day. Ocular pressure peak in horses happens at the end of the day and the amplitude of variation is between 4 and $5 \mathrm{mmHg}$ (BERTOLUCCI et al., 2009). To minimize the circadian rhythm influence on IOP, this study was performed in an interval of two hours. Many other factors; however, can influence intraocular pressure, among which are fluid intake and venous blood pressure (GWIN et al., 1979), this way IOP measurements were made in the same day to avoid daily fluctuations.

Head position has a significant effect on the IOP of horses. IOP is significantly increased with the head below heart level, compared with IOP in the head-up position. For this reason, tonometry should be performed in the head-up position in horses (KOMÁROMY et al., 2006). During the IOP measurements special care was taken to keep the head above heart level.

\section{CONCLUSION}

Restraint of horses with upper lip twitch increases significantly equine intraocular pressure measured with rebound tonometry. For this reason, the lip twitch is not recommended for IOP evaluation in horses and could take the clinician to mistaken ophthalmic diseases diagnoses.

\section{ACKNOWLEDGMENT}

We would like to thank Estância de São Pedro Farm for supplying the horses used in this study.

\section{BIOETHICS AND BIOSSECURITY COMMITTEE APPROVAL}

This study was approved by the Research Committee of the Faculty of Veterinary of the Universidade Federal do Rio Grande do Sul (UFRGS), and followed the ethical norms of the Association for Research in Vision and Ophthalmology (ARVO).

\section{REFERENCES}

BERTOLUCCI, C. et al. Circadian intraocular pressure rhythms in athletic horses under different lighting regime. Chronobiology International, v.26, n.2, p.348-358, 2009. Available from: <http:// informahealthcare.com/doi/abs/10.1080/07420520902751035>. Accessed: Sept. 16, 2014. doi: 10.1080/07420520902751035.

BROADWATER, J.J. et al. Ophthalmic examination findings in adult pygmy goats (Capra hicus). Veterinary Ophthalmology, v.10, n.5, p.269-273, 2007. Available from: $<$ http://onlinelibrary.wiley.com/doi/10.1111/j.14635224.2007.00548.x/full>. Accessed: Mar. 10, 2015. doi: 10.1111/j.1463-5224.2007.00548.x.

CARASTRO, S.M. Equine ocular anatomy and ophthalmic examination. The Veterinary Clinics of North America. Equine Practice, v.20, p.285-299, 2004.

COLBORN, D.R. et al. Responses of cortisol and prolactin to sexual excitement and stress in stallions and geldings. Journal of Animal Science, v.69, p.2556-2562, 1991. Available from: $<$ http://www.journalofanimalscience.org/content/69/6/2556.full. pdf + html $>$. Accessed: Sept. 16, 2014.

GERMANN, S.E. et al. Effects of topical administration of $1 \%$ brinzolamide on intraocular pressure in clinically normal horses. Equine Veterinary Journal, v.40, n.7, p.662665 , 2008. Available from: <http://onlinelibrary.wiley.com/ doi/10.2746/042516408X297426/epdf>. Accessed: Mar. 10, 2015. doi: 10.2746/042516408X297426.

GUM, G.G. et al. Intraocular pressure in normal dairy cattle. Veterinary Ophthalmology, v.1, p.159-161, 1998. Available from: <http://web.a.ebscohost.com/ehost/pdfviewer/ pdfviewer?sid=0b2ffcbf-d732-4903-903a-b129dc53101c\%40ses sionmgr4003\&vid $=1 \&$ hid $=4104>$. Accessed: Mar. 10, 2015. doi: 10.1046/j.1463-5224.1998.00017.x.

GWIN, R.M. et al. Adrenergic and cholinergic innervation of the anterior segment of the normal and glaucomatous dog. Investigative Ophthalmology \& Visual Science, v.18, n.7, p.674682, 1979. Available from: <http://www.iovs.org/content/18/7/674. full.pdf $>$. Accessed: Sept. 18, 2014.

JEONG, M. et al. Comparison of the rebound tonometer (TonoVet) with the applanation tonometer (TonoPen XL) in normal Eurasian eagle owls (Bubo bubo). Veterinary Ophthalmology, v.10, n.6, p.376-379, 2007. Available from: <http://onlinelibrary.wiley.com/ doi/10.1111/j.1463-5224.2007.00573.x/epdf>. Accessed: Jun. 14, 2015. doi: 10.1111/j.1463-5224.2007.00573.x. 
KNOLLINGER, A.M. et al. Evaluation of a Rebound tonometer for measuring intraocular pressure in dogs and horses. Journal of American Veterinary Association, v.46, n.2, p.244-248, 2005.

KOMÁROMY, A.M. et al. Effect of head position on intraocular pressure in horses. American Journal of Veterinary Research, v.67, n.7, p.1232-1235, 2006. Available from: <https://www.med.upenn. edu/cpob/documents/Effectofheadpositiononintraocularpressure. pdf $>$. Accessed: Mar. 10, 2015.

LEIVA, M. et al. Comparison of the rebound tonometer (ICare ${ }^{\circledR}$ ) to the applanation tonometer (Tonopen $\mathrm{XL}^{\circledR}$ ) in normotensive dogs. Veterinary Ophthalmology, v.9, n.1, p.17-21, 2006. Available from: <http://onlinelibrary.wiley.com/doi/10.1111/ j.1463-5224.2005.00429.x/epdf $>$. Accessed: Jun. 14. 2015. doi: 10.1111/j.1463-5224.2005.00429.x.

LÓPEZ-CABALLERO, C. et al. Rebound tonometry in a clinical setting. Comparison with applanation tonometry. Archivos de la Sociedad Española de Oftalmología, v.82, p.273-278, 2007. Available from: <http://scielo.isciii.es/pdf/aseo/v82n5/original2. pdf $>$. Accessed: Jun. 14, 2015.

PEREIRA, F.Q. et al. Comparison of a rebound and an applanation tonometer for measuring intraocular pressure in normal rabbits. Veterinary Ophthalmology, v.1, n.5, p.321-326, 2011. Available from: <http://onlinelibrary.wiley.com/doi/10.1111/ j.1463-5224.2011.00879.x/pdf $>$. Accessed: Sept. 18, 2014. doi: 10.1111/j.1463-5224.2011.00879.x.

PIGATTO J.A.T. et al. Intraocular pressure measurement in sheep using an applanation tonometer. Revista Ceres, v.58, n.6, p.678-679, 2011. Available from: <http://www.scielo. br/scielo.php? pid $=$ S0034-737X2011000600002\& script $=$ sci arttext>. Accessed: Mar. 03, 2015. doi: 10.1590/S0034737X2011000600002.

RAMSEY, D.T. et al. Corneal thickness, intraocular pressure and optical corneal diameter in Rocky Mountain Horses with cornea globosa or clinically normal corneas. American Journal of Veterinary Research, v.60, n.10, p.1317-1321, 1999.
RUSANEM, E. et al. Evaluation of a rebound tonometer (Tonovet) in clinically normal cat eyes. Veterinary Ophthalmology, v.13, n.1, p.31-36, 2010. Available from: <http://onlinelibrary.wiley. com/doi/10.1111/j.1463-5224.2009.00752.x/pdf > . Accessed: Sept. 18, 2014. doi: 10.1111/j.1463-5224.2009.00752.x.

TO, C. et al. The mechanism of aqueous humor formation. Clinical and Experimental Optometry, v.85, n.6, p.335349, 2002. Available from: <http://onlinelibrary.wiley.com/ doi/10.1111/j.1444-0938.2002.tb02384.x/pdf>. Accessed: Sept. 18, 2014. doi: 10.1111/j.1444-0938.2002.tb02384.x.

TRIM, C.M. et al. Effect of xylazine and ketamine on intraocular pressure in horses. Veterinary Record, v.117, p.442-443, 1985.

VAN DER WOERDT, A. et al. Effect of auriculopalpebral nerve block and intravenous administration of xylazine on intraocular pressure and corneal thickness in horses. American Journal of Veterinary Research, v.56, n.2, p.155-158, 1995.

WADA, S. Changes of intraocular pressure in uveitic horses. Journal of Equine Science, v.17, n.3, p.67-73, 2006.

WANG, W.H. et al. Noninvasive measurement of rodent intraocular pressure with a rebound tonometer. Investigative Ophthalmology \& Visual Science, v.46. p.4617-4621, 2005. Available from: $<$ http://www.iovs.org/content/46/12/4617.long>. Accessed: Sept. 18, 2014. doi: 10.1167/iovs.05-0781.

WHITACRE M.M.; STEIN, R. Souces of error with the use of Goldmann-type tonometers. Survey of Ophthalmology, v.38, n.1, p.1-27, 1993. Available from: <http://ac.els-cdn. com/003962579390053A/1-s2.0-003962579390053A-main.pdf? $\mathrm{tid}=155 \mathrm{~b} 1646-\mathrm{c} 78 \mathrm{a}-11 \mathrm{e} 4-8 \mathrm{c} 47-00000 \mathrm{aacb} 35 \mathrm{f} \& \mathrm{acdnat}=142603 \overline{5}$ 840 446c068b1fb890fde74b1ab8992383e5>. Accessed: Mar. 10, 2015. doi: 10.1016/0039-6257(93)90053-A.

WILKIE, D.A.; GILGER, B.C. Equine glaucoma. The Veterinary Clinics of North America. Equine Practice, v.20, p.381-391, 2004. Available from: <http://www.sciencedirect.com/science/ article/pii/S0749073904000203>. Accessed: Mar. 10, 2015. doi: 10.1016/j.cveq.2004.04.002. 